\title{
Hubungan Pengetahuan dan Sikap dengan Tindakan Pencegahan Penularan HIV-AIDS pada Waria di Kota Padang Tahun 2013
}

\author{
Vicca Rahmayani, Akmal M.Hanif, Susila Sastri
}

\begin{abstract}
Abstrak
Kasus HIV/AIDS di Provinsi Sumatera barat sampai Desember 2012 sebanyak 133 kasus positif HIV dan 120 kasus AIDS, jumlah kasus terbesar di kota Padang sebesar 78,94\%. Faktor resiko paling banyak melalui hubungan seksual sebesar $32 \%$, dan di antara 40 orang waria penjaja seks dibawah bimbingan LSM APP(Aia Pacah Peduli) dinyatakan 5 waria +HIV. Tujuan penelitian untuk menganalisa hubungan pengetahuan dan sikap dengan tindakan pencegahan penularan HIV-AIDS pada waria di kota Padang. Metode penelitian adalah analitik observasional dengan pendekatan cross sectional study. Populasi penelitian adalah para waria penjaja seks dibawah bimbingan LSM APP Padang. Penentuan jumlah sampel menggunakan teknik total sampling dengan jumlah sampel 40 waria penjaja seks. Analisis data menggunakan uji statistik chi-square. Hasil penelitian menunjukkan bahwa $65 \%$ waria penjaja seks memiliki tindakan yang baik, 70\% memiliki pengetahuan yang tinggi, dan $52,5 \%$ menunjukkan sikap sedang terhadap pencegahan penularan HIV-AIDS. Hasil uji chi-square menunjukkan bahwa ke dua variabel independen berhubungan secara bermakna dengan variabel dependen $(p<0,05)$ yaitu variabel pengetahuan $(p=$ 0,040) dan sikap $(p=0,048)$.
\end{abstract}

Kata kunci: Pengetahuan, Sikap, Tindakan, HIV-AIDS, Waria penjaja seks

\section{Abstract}

Cases of HIVIAIDS in West Sumatra province until December 2012, is as many as 133 cases of HIV positive and 120 cases of AIDS, with the largest number is occured in Padang city that is $79.3 \%$. The most influenced risk factor is through a sexual relationship amounted to $32 \%$, and among the 40 transvestites sex workers who have been under the guidance of the APP (Aia Pacah Peduli)—an NGO, there are 5 transvestites with + HIV. This research aims to analyze the relationship of knowledge and attitude with the precautions of HIVIAIDS transmission on transvestites in Padang city. Methode of this research is an observational analytic study with cross sectional study approach. Population were all transvestites sex workers (40) who have been under the guidance of the APP (Aia Pacah Peduli)an NGO that is 40. The amount of this sample is chosen using total sampling. Data analysis uses statistical test of chisquare. The research results showed that $65 \%$ of transvestites sex workers take good preventive action, $70 \%$ had high knowledge, and 52.5\% show that they took sufficient attitude related to prevention of HIVIAIDS transmission. Chisquare test results showed that the two independent variables are significantly correlated with the dependent variable $(p<0,05)$, that is knowledge variable $(p=0,040)$ and attitude $(p=0,048)$.

Keywords: Knowledge, Attitude, Action, HIV/AIDS, Transvestites sex workers

Affiliasi penulis : Fakultas Kedokteran Universitas Andalas Korespondensi: Vicca Rahmayani, email Viccharahmayani@yahoo.co.id, Telp: 085363347564

\section{PENDAHULUAN}

Penyakit menular hingga saat ini masih menjadi masalah utama kesehatan masyarakat Indonesia dan merupakan penyebab tersering mengakibatkan kematian pada penderitanya. Kementerian kesehatan Indonesia telah menyusun prioritas sasaran penanggulangan penyakit menular dalam rencana strategis kementerian kesehatan tahun 2010 - 2014. Penyakit yang menjadi prioritas tersebut diantaranya adalah HIV/AIDS (Human Immunodeficiency Virus / Acquired Immunodeficiency Syndrome), TB (Tuberkulosis) paru, diare, pneumonia, dan kusta.

AIDS (Acquired Immunodeficiency Syndrome) pertama kali diidentifikasi pada tahun 1981 di Amerika Serikat. Penyebab AIDS adalah infeksi virus HIV (Human Immunodeficiency Virus) golongan famili retroviridae yang menginfeksi sistem imun terutama CD4+ sel T. ${ }^{1}$

Berdasarkan data SEARO (South East Asia Regional Office) tahun 2011, India, Indonesia, Myanmar, Nepal dan Thailand merupakan negara dengan penyebaran HIV/AIDS terbesar. Negara diurutan pertama adalah India, diperkirakan 2,4 juta penduduknya menderita HIV/AIDS. Sedangkan Indonesia berada di urutan ke empat dengan jumlah penderita HIV/AIDS sebanyak 190.000 jiwa. $^{2}$

Indonesia merupakan negara dengan peningkatan kasus HIV/AIDS tercepat di Asia, dari 5 kasus AIDS pada tahun 1987 menjadi 31.000 kasus AIDS dan menunjukkan peningkatan rata-rata $50 \%$ per tahun. Kelompok terbesar penderita HIV/AIDS adalah kelompok berusia produktif di antara 20 - 29 tahun yang menyumbang sekitar $37,1 \%$ dari keseluruhan penderita HIV/AIDS. Sementara prevalensi HIV menurut kelompok responden, sebesar 42,4\% HIV/AIDS diderita oleh penasun (pengguna narkoba suntik), Waria 23,2\%, WPS (Wanita Penjaja Seks) 
langsung 9,3\%, Lelaki Seks Lelaki (LSL) 12,4\%, WPS tidak langsung $3,1 \%$ dan lain-lain 0,7\%. Sekitar $87 \%$ waria yang menjadi yang menjadi responden STBP 2009 di 9 kota mengaku pernah menjual seks kepada pelanggan laki-laki dalam 1 tahun terakhir. Sebagian besar pelanggan dilayani seks anal dengan tingkat konsistensi pemakaian kondom hanya $35,9 \%$ saja. Dengan perilaku yang lebih beresiko dibanding penjaja seks lainnya, maka cukup wajar bila rata-rata prevalensi HIV pada waria lebih tinggi dari penjaja seks lainnya. ${ }^{3}$

Provinsi yang memiliki angka kasus AIDS terbanyak adalah DKI Jakarta, sedangkan Sumbar terletak pada urutan ke-19 dari 33 provinsi yang dilaporkan. ${ }^{4}$ Kasus HIV di Sumbar pertama kali di diagnosis tahun 1992 dan kasus AIDS tahun 1999 serta sejak itu setiap tahun kasusnya selalu meningkat dan di temukan kasus-kasus baru. ${ }^{5}$ Berdasarkan laporan Ditjen PP dan PL Kemenkes RI tahun 2013, sampai Desember 2012 ditemukan 133 kasus positif HIV dan 120 kasus AIDS di Sumbar. Dari jumlah kasus tersebut, faktor resiko yang paling banyak melalui hubungan seksual sebesar $32 \%$ dan banyak pada laki-laki sekitar $62 \%$ dengan pekerjaan paling banyak wiraswasta. ${ }^{5}$

Kasus HIV/AIDS di Provinsi Sumatera Barat saat ini sudah menyebar hingga ke semua kabupaten/kota dengan jumlah kasus terbesar di kota Padang sebesar 78,94\% dan kota Bukittinggi sebesar $21,05 \%$. ${ }^{6}$ Data dari LSM APP Padang hingga Maret 2013, tercatat telah memberikan dampingan pada waria khususnya waria penjaja seks sebanyak 40 orang. Dari data tersebut dinyatakan 5 waria positif HIV.

Waria merupakan salah satu kelompok risiko tinggi penyebar HIV/AIDS, keberadaannya saat ini cukup mengkhawatirkan karena aktivitas yang melekat dalam keseharian mereka. Aktivitas seksual pada waria sebagai pekerja seksual dianggap berisiko tinggi karena mereka mempunyai banyak pasangan seksual pria dan kemungkinan besar pasangan mereka juga mempunyai banyak pasangan seksual pria lainnya, baik pria yang sudah/belum menikah. ${ }^{7}$

Selain itu, prevalensi IMS dan HIV yang masih cukup tinggi pada waria selaras dengan buruknya distribusi kondom dan pelumas, rendahnya pemahaman tentang manfaat pelayanan klinik dan rendahnya dukungan terhadap waria yang $+\mathrm{HIV}$. Situasi ini membuat upaya untuk menanggulangi masalah HIV pada waria cukup sulit. Hampir semua waria penjaja seks selama 10 tahun terakhir mengalami situasi ini. Kemiskinan, pendidikan yang rendah dan diskriminasi bersamaan dengan sulitnya mendapatkan kartu karena identitas menyulitkan mereka untuk mendapatkan pekerjaan. Kesulitan memperoleh kartu identitas membatasi mereka untuk mendapatkan akses terhadap pelayanan kesehatan. Perilaku seks mereka yang beresiko menempatkan mereka, klien mereka dan pasangan seks mereka beresiko tinggi untuk tertular HIV.

Masalah utama yang dihadapi waria khususnya yang terlibat sebagai penjaja seks adalah negosiasi untuk pemakaian kondom. Akses terhadap pelayanan kesehatan juga merupakan masalah yang cukup sulit bagi waria karena masalah kartu identitas dan masalah lainnya termasuk diskriminasi, tidak sensitifnya pelayanan kesehatan dan kurangnya pengetahuan pelayanan kesehatan tentang waria.
Program pencegahan terhadap HIV/AIDS dengan komunikasi informasi dilakukan kepada kelompok resiko tinggi termasuk waria dan terutama waria penjaja seks, namun kenyataanya penderita HIV/AIDS yang merupakan waria terutama waria penjaja seks masih mengalami penambahan tiap tahunnya.

Dari hasil wawancara awal dengan kepala LSM APP Padang, sebagian besar waria penjaja seks sudah memiliki pengetahuan yang cukup tinggi tentang bahaya, penularan, dan pencegahan penyakit HIV/AIDS. Namun pada kenyataannya waria tetap melakukan perilaku seksual yang beresiko tersebut dengan berbagai macam alasan salah satunya adalah kepuasan pelanggan mereka. Hal ini memungkinkan untuk tertular HIV-AIDS sangat besar.

Menurut temuan kunci pada STBP, angka prevalensi HIV dan menular seksual (IMS) pada waria sangat tinggi di tiga kota yang menjadi lokasi pengumpulan data biologis. Tiga kota tersebut adalah Jakarta, Surabaya, dan bandung, dan jumlah waria dengan HIV terbanyak berada di kota Jakarta sebesar $34 \%$ dari jumlah penderita HIV keseluruhan. Untuk kota Padang atau Sumbar, belum pernah dilakukan penelitian STBP yang menyangkut HIV pada waria. Dan tidak tertutup kemungkinan bahwa waria di kota Padang juga merupakan kelompok yang beresiko untuk tertular ataupun menularkan HIV/AIDS kepada pelanggannya. Tujuan hubungan pengetahuan dan sikap dengan tindakan pencegahan penularan HIVIAIDS pada waria di kota Padang tahun 2013".

\section{METODE}

Jenis penelitian yang digunakan adalah jenis analitik observasional dengan pendekatan cross sectional. Populasi penelitian adalah para waria penjaja seks yang berada dibawah bimbingan LSM APP Padang, dimana hingga Maret 2013 tecatat sebanyak 40 waria. Sampel penelitian adalah seluruh populasi yang ada pada penelitian ini. Kriteria inklusi adalah waria penjaja seks yang masih aktif, telah tinggal di kota Padang paling kurang selama satu bulan, berusia antara 20-40 tahun, dan bersedia untuk diwawancara dengan menggunakan kuesioner sebagai pedoman wawancara. Kriteria eksklusi antara lain waria yang menderita penyakit berat selama penelitian berlangsung dan mendadak tidak bisa di temui saat penelitian berlangsung. Penelitian dilaksanakan pada Mei 2013.

Variabel independen penelitian adalah pengetahuan dan sikap pencegahan penularan HIVAIDS. Tingkat pengetahuan merupakan hasil "tahu" dan hal ini terjadi setelah sebelumnya melakukan pengindraan terhadap suatu objek tertentu. Tingkat pengetahuan yang di ukur adalah hal-hal yang diketahui tentang HIV-AIDS, meliputi pengertian, penyebab, cara penularan, gejala, dan cara pencegahan HIV-AIDS. Sikap merupakan respon yang masih tertutup dari waria (pernyataan setuju atau tidak setuju) terhadap pernyataan-pernyataan yang berkaitan dengan HIV-AIDS. Sikap ini dibagi atas dua kategori yaitu pernyataan setuju dan tidak setuju. Data didapatkan melalui wawancara dengan alat ukur kuesioner. Hasil ukur pengetahuan rendah bila total skor 8-14 dan pengetahuan tinggi bila total skor 15-24, sedangkan sikap dianggap kurang jika total skor $<2$, sikap sedang jika total skor 2-3, dan sikap baik, jika total skor 4-5. Variabel dependen penelitian adalah 
tindakan pencegahan merupakan suatu kegiatan atau aktivitas yang dilakukan oleh waria tentang tindakan nyata untuk mencegah terinfeksi HIV-AIDS. Cara ukur yang digunakan dengan wawancara menggunakan kuisioner. Hasil ukur tindakan buruk jika total skornya 1-3 dan tindakan baik, jika total skornya 4-5.

Langkah-langkah pengolahan data yang dilakukan yaitu memeriksa kelengkapan data dari kuesioner, memberikan kode pada setiap data variabel yang telah terkumpul, memasukkan data ke dalam komputer dengan program Statistical Program for Social Science (SPSS) 17.0, dan memeriksa kembali data yang telah dimasukkan untuk memastikan bahwa data tersebut telah bersih dari kesalahan. Analisis data terdiri dari analisis univariat dan bivariat. Analisis bivariat digunakan untuk menganalisis antara dua variabel yaitu variabel independen meliputi pengetahuan dan sikap dengan variabel dependen yaitu tindakan waria dalam pencegahan penularan HIV-AIDS menggunakan uji Chi Square dengan derajat kemaknaan $p \leq 0,05$.

\section{HASIL}

\section{Karakteristik Responden}

Setengah dari responden berada dalam kelompok umur 26-30 tahun (50\%) sebanyak 20 orang. Sebagian besar responden memiliki tingkat pendidikan baik dengan menyelesaikan pendidikan SMA/SMK (45\%) sebanyak 18 orang.

\section{Tindakan}

Tabel 1. Distribusi Frekuensi Tindakan Waria

\begin{tabular}{lll}
\hline Tindakan & Frekuensi & $\%$ \\
\hline Baik & 26 & 65 \\
Buruk & 14 & 35 \\
\hline umlah & $\mathbf{1 4 5}$ & $\mathbf{1 0 0}$ \\
\hline
\end{tabular}

Berdasarkan tabel 1 diatas diketahui bahwa lebih dari separuh responden (65\%) yaitu sebanyak 26 orang responden melakukan tindakan pencegahan penularan HIV-AIDS dengan cara yang baik.

\section{Pengetahuan}

Pada penelitian ini distribusi frekuensi responden berdasarkan tingkat pengetahuan responden, yang di ukur adalah hal-hal yang diketahui tentang HIV-AIDS, meliputi pengertian, penyebab, cara penularan, gejala, dan cara pencegahan HIVAIDS

Tabel 2. Distribusi Frekuensi Pengetahuan Waria

\begin{tabular}{lll}
\hline Pengetahuan & Frekuensi & $\%$ \\
\hline Tinggi & 28 & 70 \\
Rendah & 12 & 38 \\
\hline Jumlah & $\mathbf{1 4 5}$ & $\mathbf{1 0 0}$ \\
\hline
\end{tabular}

Berdasarkan tabel 2 diatas diketahui bahwa lebih dari separuh $(70 \%)$ responden memiliki tingkat pengetahuan yang tinggi terhadap HIV-AIDS dengan jumlah responden sebanyak 28 orang responden.

\section{Sikap}

Pada penelitian ini distribusi frekuensi responden berdasarkan sikap responden, respon yang masih tertutup dari waria (pernyataan setuju atau tidak setuju) terhadap pernyataan-pernyataan yang berkaitan dengan HIV-AIDS.

Tabel 3. Distribusi Frekuensi Sikap Waria

\begin{tabular}{lll}
\hline Sikap & Frekuensi & (\%) \\
\hline Baik & 13 & 32,5 \\
Sedang & 21 & 52,5 \\
Kurang & 6 & 15,0 \\
\hline Jumlah & $\mathbf{1 4 5}$ & $\mathbf{1 0 0}$ \\
\hline
\end{tabular}

Berdasarkan tabel 3 diatas diketahui bahwa sikap sedang dalam pencegahan penularan HIV-AIDS lebih banyak ditunjukkan oleh responden (52,5\%) dengan dengan jumlah responden sebanyak 21 orang responden.

\section{Analisis bivariat}

Pada penelitian ini, untuk melihat hubungan dari masing-masing variabel, baik independen (sikap dan pengetahuan) dan variabel dependen (tindakan) maka dilakukan uji chi square.

Tabel 4. Hubungan Tingkat Pengetahuan dengan Tindakan Pencegahan

\begin{tabular}{ccccccc}
\hline \multirow{2}{*}{ Pengetahuan } & \multicolumn{2}{c}{ Tindakan } & $F$ & $\%$ & $P$ \\
\cline { 2 - 5 } & $\begin{array}{c}\text { Bai } \\
\text { k }\end{array}$ & $\begin{array}{c}\text { Buru } \\
\mathbf{k}\end{array}$ & & & \\
\cline { 1 - 5 } Pengetahuan Tinggi & 21 & 7 & 28 & $70 \%$ & \multirow{2}{*}{0,040} \\
Pengetahuan Rendah & 5 & 7 & 12 & $30 \%$ & \\
\cline { 1 - 5 } Total & 26 & 14 & 40 & $100 \%$ & \\
\hline
\end{tabular}

Berdasarkan tabel 4 hasil analisis hubungan antara tingkat pengetahuan dengan tindakan pencegahan penularan penyakit HIV-AIDS, didapatkan hubungan yang bermakna antara keduanya $(p<0,05$ yaitu 0,040$)$. Lebih dari separuh (21 orang responden) memiliki pengetahuan yang tinggi dan tindakan yang baik dalam hal pencegahan.

Tabel 5. Hubungan Sikap dengan Tindakan Pencegahan

\begin{tabular}{cccccc}
\hline \multirow{2}{*}{ Sikap } & \multicolumn{2}{c}{ Tindakan } & $\mathrm{F}$ & $\%$ & $\mathrm{P}$ \\
\cline { 2 - 5 } & Baik & Buruk & & & \\
\hline Baik & 10 & 3 & 13 & 32,5 & \\
Sedang & 14 & 7 & 21 & 52,5 & 0,048 \\
Kurang & 2 & 4 & 6 & 15,0 & \\
\hline Total & 26 & 14 & 40 & 100,0 & \\
\hline
\end{tabular}

Berdasarkan tabel 5 hasil analisis hubungan antara sikap dengan tindakan pencegahan penularan penyakit HIV-AIDS, didapatkan hubungan yang bermakna antara keduanya $(p<0,05$ yaitu 0,048$)$. Responden dengan tindakan pencegahan yang baik lebih tinggi pada sikap sedang (14 orang responden) dibandingkan dengan tindakan pencegahan pada sikap baik dan sikap kurang.

\section{PEMBAHASAN}

\section{Umur Responden}


Berdasarkan hasil penelitian yang dilakukan menunjukkan bahwa $50,0 \%$ responden (waria) terbanyak adalah responden (waria) yang berusia 2630 tahun dengan jumlah responden sebanyak 20 orang responden. Umur responden termuda ditemukan 21 tahun dan umur tertua 36 tahun.

\section{Pendidikan responden}

Berdasarkan hasil penelitian yang dilakukan menunjukkan bahwa responden (waria) memiliki tingkat pendidikan yang paling tinggi adalah SMA/SMK. Hal ini sesuai dengan Notoatmodjo (2005) bahwa tingkat pendidikan seseorang dapat meningkatkan pengetahuan khususnya pengetahuan di bidang kesehatan. Semakin tinggi tingkat pendidikan seseorang semakin mudah menyerap informasi termasuk juga informasi kesehatan sehingga mereka tahu bagaimana cara pencegahan dan penularan penyakit HIV-AIDS. ${ }^{9}$

\section{Tindakan Waria dalam pencegahan penyakit HIV-AIDS}

Berdasarkan hasil penelitian menunjukkan bahwa $65 \%$ responden melakukan tindakan baik terhadap pencegahan penularan HIV-AIDS dengan jumlah responden sebanyak 26 orang responden. Angka tersebut menunjukkan bahwa waria penjaja seks di kota Padang sebagian besar memiliki tindakan baik dalam pencegahan penularan HIV/AIDS. Hal ini dapat berdampak positif dalam menekan laju penularan HIV/AIDS.

Pernyataan yang diberikan responden melalui kuesioner yang menunjukkan tindakan baik adalah menganjurkan pelanggan menggunakan kondom dengan merayu $(70 \%)$, bersedia memakaikan kondom pada pelanggan $(97,5 \%)$, menolak berhubungan seks jika pelanggan tidak menggunakan kondom $(67,5 \%)$, dan menyadari bahwa pekerjaan mereka adalah pekerjaan yang terancam tertular HIV/AIDS sehingga akan berusaha melakukan tindakan pencegahan terhadap HIV/AIDS (95\%). Namun, pada pernyataan menggunakan kondom ketika berhubungan seks dengan pelanggan hanya $67,5 \%$ yang menyatakan selalu menggunakan kondom, sedangkan sisanya menyatakan kadangkadang dan tidak pernah. Hal ini terkait dengan pernyataan dari pelanggan waria yang merasa tidak nyaman saat menggunakan kondom ketika berhubungan seks, keadaan ini merupakan salah satu faktor yang mempengaruhi tindakan pencegahan yang akan dilakukan oleh waria. Oleh sebab itu, dibutuhkan pemberian pemahaman tidak hanya kepada waria tetapi juga kepada pelanggan waria untuk melakukan tindakan pencegahan penularan agar tidak terinfeksi oleh HIV/AIDS

Dari hasil penelitian diperoleh bahwa lebih dari separuh responden (65\%) menunjukkan tindakan pencegahan penularan HIV/AIDS baik. Hal ini berarti responden telah memiliki tindakan yang baik terhadap hal-hal yang berhubungan dengan HIV/AIDS dan melakukan tindakan-tindakan pencegahan penularan HIV/AIDS untuk mencegah penyebarluasan HIV/AIDS. Namun masih terdapat tindakan yang buruk dalam pencegahan HIV/AIDS sebanyak $35 \%$ responden, jika tetap berlangsung tanpa ada binaan pemahaman yang lebih pada waria dan pelanggannya akan berakibat meningkatkan penularan HIV/AIDS di kalangan mereka. Oleh sebab itu, di butuhkan kerjasama antara pihak terkait (LSM dan KPA) untuk memberikan pemahaman yang lebih pada kelompok beresiko tertular HIV/AIDS khususnya waria penjaja seks untuk melakukan tindakan pencegahan penularan HIV/AIDS agar tidak terinfeksi oleh HIV/AIDS.

\section{Pengetahuan}

Berdasarkan hasil penelitian menunjukkan bahwa lebih dari separuh responden yaitu sebanyak $70 \%$ memiliki tingkat pengetahuan yang baik terhadap HIV-AIDS dengan jumlah responden sebanyak 28 waria. Hal ini membuktikan bahwa sebagian besar dari responden telah mengetahui pengertian, penyebab, cara penularan, gejala, dan cara pencegahan HIV/AIDS.

Hasil penelitian ini berbeda dengan hasil penelitian yang dilakukan oleh Sutri Ana Sianturi di kabupaten Serdang Bedagai Provinsi Sumatera Utara tahun 2012 tentang hubungan faktor predisposisi, pendukung, dan penguat dengan tindakan penggunaan kondom pada WPS, hasilnya menemukan sebanyak $91,8 \%$ respondennya berpengetahuan kurang tentang HIV/AIDS. ${ }^{1}$

Pengetahuan yang cukup tinggi pada responden kemungkinan dapat di sebabkan oleh karena sebelumnya responden pernah mendapatkan penyuluhan tentang HIV/AIDS dan bimbingan dalam pencegahan penularan HIV/AIDS dari LSM terkait. Dilihat dari pilihan jawaban pertanyaan pada kuesioner yang diajukan, pada umumnya waria sudah mengetahui pengertian dari HIV/AIDS (81\%), cara penularan HIV/AIDS (74\%), pencegahan penularan HIV/AIDS (86\%), pengertian, kegunaan, dan cara penggunaan $(54 \%, 86 \%$, dan $74 \%)$, akibat tidak menggunakan kondom (88\%), dan kelompok yang beresiko tertular HIV/AIDS (61\%). Dari hasil yang didapatkan, dapat disimpulkan bahwa pengetahuan waria tentang HIV/AIDS cukup baik dan rata-rata waria sudah mengetahui apa penyebab HIV/AIDS, bagaimana pencegahan HIV/AIDS, dan apa saja akibat dari tertularnya HIV/AIDS.

Pengetahuan waria di kota Padang secara umum tentang HIV/AIDS cukup tinggi, namun masih terdapat sebagian kecil waria yang memiliki pengetahuan kurang tentang HIV/AIDS. Oleh sebab itu masih perlu di sampaikan informasi lebih dalam dan merata kepada semua responden mengenai pengertian dan hubungan HIV dan AIDS, cairan tubuh yang mengandung HIV, cairan tubuh yang menjadi penularan HIV, faktor resiko penularan HIVIAIDS, dan pencegahan penularan HIV/AIDS.

\section{Sikap}

Berdasarkan hasil penelitian di dapatkan sebanyak $52,5 \%$ responden memiliki sikap sedang terhadap pencegahan HIV/AIDS. Angka tersebut menunjukkan bahwa lebih dari separuh responden mempunyai sikap sedang dalam pencegahan penularan HIV/AIDS.

Pernyataan sikap terbagi atas 2 kategori yaitu pernyataan setuju dan tidak setuju, persentase sikap setuju terhadap pernyataan tentang penggunaan 
kondom dengan benar pada saat berhubungan seks sebaiknya dilakukan untuk mencegah HIV/AIDS (95\%), pelanggan harus menggunakan kondom pada saat berhubungan seksual (80\%), menyarankan pelanggan untuk menggunakan kondom agar terhindar dari HIV/AIDS (80\%).

Sedangkan untuk pernyataan dengan menggunakan kondom lebih merasa aman dan pernyataan jika pelanggan menolak menggunakan kondom sebaiknya tidak melakukan hubungan seksual, masing-masing persentasenya $27,5 \%$ dan $37,5 \%$ saja yang menyatakan setuju. Hal inilah yang mengakibatkan tingginya persentase sikap sedang pada pencegahan penularan HIV/AIDS pada waria. Maksud dari sikap sedang adalah waria sudah mempunyai pengetahuan yang cukup baik tentang HIV/AIDS, tapi masih mempunyai niat atau kesadaran yang kurang untuk melakukan pencegahan HIV/AIDS. Niat atau kesadaran yang kurang bisa berasal dari waria sendiri dan bisa juga dipengaruhi oleh kemauan pelanggan atau keadaan lain di lapangan yang mengakibatkan pemakaian kondom pada pada saat berhubungan seks sulit untuk dilaksanakan secara konsisten.

Penelitian ini sejalan dengan penelitian IAKMI di Bali Tahun 2010 yang menunjukan bahwa WPS tidak mampu untuk menolak tamu yang tidak menggunakan kondom karena daya tawar mereka yang rendah. Dari sisi pelanggan, berkurangnya kenikmatan seksual saat berhubungan seks adalah alasan utama mereka menolak untuk memakai kondom. ${ }^{11} \mathrm{Hal}$ tersebut jelas tercermin dalam pernyataan 13 waria penjaja seks $(32,5 \%)$ yang menyatakan bahwa kebanyakan pelanggan tidak mau menggunakan kondom karena merasa tidak nyaman dan tidak enak ketika berhubungan seks.

Hasil dari penelitian Evianty (2008) d Lokalisasi Teleju Kota Pekan Baru bahwa WPS yang tidak menggunakan kondom sebesar $82,3 \%$ dan yang menggunakan kondom hanya $17,7 \%{ }^{12}$ Penelitian Widodo pada tahun 2009 dilokalisasi Koplak, Kabupaten Grobogan menyatakan bahwa 93\% responden tidak selalu menggunakan kondom saat berhubungan seks. ${ }^{13}$ Penelitian Catherine Dodds pada pria Afrika di Inggris (2010) menunjukan bahwa 41,4\% responden selalu menggunakan kondom, 33\% responden kadang-kadang dan $25,6 \%$ responden tidak pernah menggunakan kondom saat berhubungan seksual. ${ }^{14}$

Hasil penelitian ini berbeda dengan hasi penelitian yang dilakukan oleh Sutri Ana Sianturi di Kabupaten Serdang Bedagai Provinsi Sumatera Utara tahun 2012 tentang hubungan faktor predisposisi, pendukung, dan penguat dengan tindakan penggunaan kondom pada WPS, hasilnya menemukan sikap tentang pencegahan HIV/AIDS pada responden baik, yaitu sebanyak $76,3 \%$, sedangkan untuk sikap sedang sebanyak $22,7 \%$. ${ }^{10}$

6. Hasil Pengujian Hipotesis

\section{- Hubungan Antara Tingkat Pengetahuan Dengan} Tindakan Pencegahan Penularan HIV-AIDS

Berdasarkan hasil pengujian ditemukan bahwa terdapat hubungan yang bermakna antara tingkat pengetahuan dengan tindakan pencegahan penularan HIV-AIDS di kota Padang $(p=0,040)$. Hal ini membuktikan bahwa para responden sudah cukup paham dalam pencegahan penyakit ini. Tingkat pengetahuan yang cukup baik sangat dirasa berperan penting dalam pencegahan penyakit HIV-AIDS.
Tingkat pengetahuan seseorang yang baik mengenai HIV/AIDS tidak secara otomatis akan berbuat positif terhadap pencegahan penyebaran penyakit tersebut, sebaliknya pengetahuan yang rendah atau kurang mengenai HIV/AIDS belum tentu akan berbuat hal yang negatif

\section{- Hubungan Antara Sikap Dengan Tindakan Pencegahan Penularan HIV-AIDS.}

Berdasarkan hasil pengujian ditemukan bahwa terdapat hubungan yang bermakna antara sikap dengan tindakan pencegahan penularan HIVAIDS di kota Padang. Hal ini membuktikan bahwa sikap yang ditunjukkan dari para responden (waria) sudah cukup baik dalam tindakan pencegahan penularan HIV-AIDS. Terbukti dengan sangat baiknya respon yang peneliti dapatkan dalam pengumpulan data (kuesioner). Responden (waria) memberikan keterangan dan informasi yang sangat bermanfaat sekali demi kelancaran penelitian ini. Hubungan yang bermakna antara sikap responden dengan tindakan pencegahan penularan HIV-AIDS kemungkinan disebabkan oleh pertanyaan yang diajukan kepada responden merupakan pertanyaan sikap yang hanya mencakup pertanyaan yang dikhususkan tentang bahaya dan resiko serta bagaimana cara pencegahannya sehingga sikap responden yang sebagian besar dikategorikan sedang (mendekati baik) sejalan dengan tindakan pencegahan penularan HIV/AIDS yang seharusnya juga dikategorikan baik.

\section{KESIMPULAN}

Berdasarkan hasil penelitian yang telah dilakukan, maka didapatkan kesimpulan bahwa:

1. Didapatkan lebih dari separuh responden memiliki tingkat pengetahuan yang baik terhadap HIV-AIDS

2. Didapatkan lebih dari separuh responden memiliki sikap sedang dan baik terhadap pencegahan HIV/AIDS.

3. Didapatkan lebih dari separuh responden melakukan tindakan baik terhadap pencegahan penularan HIV-AIDS.

4. Terdapat hubungan yang bermakna antara tingkat pengetahuan dengan tindakan pencegahan penularan HIV-AIDS di kota Padang.

5. Terdapat hubungan yang bermakna antara sikap dengan tindakan pencegahan penularan HIV-AIDS di kota Padang.

\section{DAFTAR PUSTAKA}

1. Djoerban Z dan Djauzi S. HIV/AIDS di Indonesia. Buku Ajar IImu Penyakit Dalam Jilid III Edisi IV. Jakarta: Pusat Penerbitan Departemen IImu Penyakit Dalam Fakultas Kedokteran UI. 2006.

2. WHO, Regional Office for South-East Asia. HIV/AIDS in the South-East Asia Region of "Progress Report 2011". India. 2012.

3. STBP. Surveilans Terpadu Biologis Perilaku pada Kelompok Berisiko Tinggi di Indonesia tahun 2007. Jakarta. 2012

4. Depkes RI. Pengendalian HIV-AIDS di Indonesia 2012 (diunduh 12 Maret 2013). Tersedia dari URL: $\quad$ HYPERLINK http://www.depkes.go.id/index.php/berita/pressrelease/1851-pengendalian-hiv-aids-diindonesia.html

5. Dinkes Kota Padang. Laporan tahunan tahun 
2011 edisi terbit tahun 2012.

6. Ditjen PP dan PL Kemenkes RI. Statistik Kasus HIV/AIDS di Indonesia dilapor s/d Desember 2012. Jakarta. 2013.

7. Komisi Penanggulangan AIDS Nasional. Strategi dan rencana aksi nasional penanggulangan HIV dan AIDS tahun 2010-2014. Jakarta: KPA Nasional. 2010.

8. USAID. Scaling Up for Most at Risk Populations: Upaya Mendukung Penanggulangan HIV/AIDS. Jakarta. 2011.

9. Notoadmojo, Soekidjo. IImu Kesehatan Masyarakat Prinsip-prinsip Dasar. Jakarta: Rineka Cipta. 2005.

10. Sianturi, Sutri Ana. Hubungan Faktor Predisposisi, Pendukung, Dan Penguat Dengan Tindakan Penggunaan Kondom Pada WPS Untuk Pencegahan HIV/AIDS Di Kabupaten Serdang Bedagai. Medan: USU. 2012.
11. Ikatan Ahli Kesehatan Masyarakat Indonesia Pengurus Daerah Bali. Laporan Penelitian Pengembangan Pelayanan Kesehatan Komprehensif Berbasis Primary Helath Care (PHC) Bagi Pekerja Seks Perempuan (PSP) di Bali. 2010.

12. Evianty, Roselly. Pengaruh Faktor Predisposisi, Pendukung dan Penguat Terhadap Tindakan PSK dalam Menggunakan Kondom untuk Pencegahan HIV/AIDS di Lokalisasi Teleju Kota Pekan Baru Tahun 2008. Medan: USU. 2008.

13. Widodo, Edy. Praktik Wanita Pekerja Seks (WPS) dalam Pencegahan Penyakit Infeksi Menular Seksual (IMS) dan HIV/AIDS di Lokalisasi Koplak, Kabupaten Grobogan, Jurnal Promosi Kesehatan Indonesia Vol.4, No.2, Agustus 2009.

14. Catherine Dodds. Male Condom Use among Africa People in England. Sigma Research. 2010. 